\title{
O HUMANO É VIÁVEL? É EDUCÁVEL?
}

\author{
BEING HUMAN IS VIABLE? HE IS EDUCABLE? \\ EL SER HUMANO ES VIABLE? ÉL ES EDUCABLE?
}

RESUMO: O texto parte de uma constatação histórica; a pedagogia nasce colada a uma crença: o humano é viável. Todo ser humano é educável. Essa crença não está em crise? Na primeira parte deste texto, apontam-se as manifestações atuais dessa descrença na viabilidade do humano e na educabilidade de jovens, adolescentes e crianças submetidos à nova segregação social e racial. Por onde passa o decretá-los e tratá-los como ineducáveis? Na segunda parte, o texto se aproxima das consequências dessas descrenças para a educação, para as teorias pedagógicas e para a formação de docentes-educadores-educadoras. Uma questão perpassa essas análises: essa descrença na viabilidade e educabilidade do humano não recoloca a centralidade da função educadora da escola e da docência? Que novas respostas de afirmação política da ética vêm das escolas?

PALAVRAS-CHAVE: Educação. Ser humano. Crianças. Segregação racial. Ética. Política.

ABSTRACT: This text initiates itself with a historical fact; the pedagogy emerges bound to a belief: the human is viable. Every human is educable. Is not this belief in crisis? In its first part, this text points out the current manifestations of this disbelief in the viability of the human and educability of the young people, adolescents and children submitted to the new social and racial segregation. Due what are they declared and treated like uneducable? In the second part, the text approaches the consequences of these disbeliefs in the education, the pedagogical theories and the formation of teachers-educators. A question passes through these analyzes: does this disbelief in the viability and educability upon the human beings revert the centrality of the education function in the school and the teaching? Which new political affirmation responses of ethic emanate from schools?

KEYWORDS: Education. Human being. Children. Racial segregation. Ethics. Policy.

RESUMEN: Este texto parte de una constatación histórica; la pedagogía nace inspirada en la certeza de que lo humano es viable y educable. Esa certeza non está en crisis? En la primera parte del texto son mostradas las manifestaciones sociales y políticas que ponen en duda la viabilidad y educabilidad de los jóvenes, adolescentes y niños pobres y negros sometidos a la nueva segregaciónsocial y racial. Porque son decretados y educables e inviables como humanos. En la segunda parte, el texto se aproxima de las consecuencias de esa nueva segregación social y racial para las teorías pedagógicas, para la formación de docentes-educadores-educadoras. Decretarlos y educables non ponen encuestión la función educadora de la escuela y del magisterio? También non provoca respuestas político-pedagógicas por reafirmar la formación ética? Que reafirmación política de la ética se da en las respuestas de las escuelas y de sus profesionales?

PALABRAS CLAVE: Educación. Ser humano. Niños. Segregación racial. Ética. Política. 
* Professor Titular Emérito da Faculdade de Educação da UFMG. Doutor em Educação pela Stanford University. Doutor Honoris Causa da Universidade Federal Fluminense.

\section{INTRODUÇÃO}

A pedagogia nasce colada a uma crença: o humano é viável. Todo ser humano é educável. A crença política em que todo cidadão é educável mobilizou a pedagogia e a docência: a educação é direito de todo cidadão. Dever do Estado. A crença na educabilidade de todo cidadão porque ele é humano alimentou as lutas pela educação, pela escola. Alimentou o preceito constitucional: o direito à educação como direito ao Desenvolvimento Humano Pleno de todo cidadão desde a infância. Não estamos em tempos de descrença dessas crenças? Consequentemente, não estaríamos em tempos de descrença na pedagogia, na escola e na docência? Por quê?

Parto da hipótese de estarmos em tempos de descrença dessas crenças e, consequentemente, de descrença na pedagogia e na docência porque nos invade a descrença na educabilidade da infância e da adolescência pobre, negra, das periferias que chegam às escolas. Estamos em tempos de uma brutal segregação social e racial desses jovens, adolescentes e até crianças, tratando-os como violentos, delinquentes, ineducáveis, logo extermináveis, entregues à justiça penal. Inviáveis como humanos.

Que o Congresso, a mídia e 80\% dos cidadãos defendam a redução da maioridade penal, defendam que o lugar de jovens, adolescentes e até crianças é na cadeia, e não na escola, é um atestado da descrença em sua educabilidade, uma descrença em sua humanidade. Um atestado de que, como humanos, são inviáveis. É um atestado de que as elites e $80 \%$ dos cidadãos não reconhecem que a escola, a pedagogia, a docência serão capazes de educar, humanizar aqueles jovens, adolescentes e crianças decretados ineducáveis, inviáveis como humanos. A defesa de que o lugar desses jovens, adolescentes e até crianças pobres, negros é na cadeia, submetidos à justiça penal, atesta a crença do fracasso das lutas políticas pela educação de todo cidadão, pelo desenvolvimento humano pleno de todo ser humano.

A crença de que o humano é viável, educável, está em crise, pondo em crise todo o humanismo social e pedagógico que inspirou a defesa do direito de todo cidadão à educação, à humanização, porque é reconhecido humano.

Na primeira parte deste texto, aproximo-me das manifestações atuais dessa descrença na viabilidade do humano, da descrença na educabilidade de jovens, adolescentes e crianças trabalhadores, negros, pobres. Por onde passa o ato de decretá-los e tratá-los como ineducáveis, inviáveis como humanos? Na segunda parte, tento me aproximar das consequências dessas descrenças para a educação, para as teorias pedagógicas, para a função formadora-humanizadora das escolas e da docência.

Uma questão perpassa essas análises: essa descrença não recoloca com centralidade na agenda política e pedagógica a função formadora da escola, da pedagogia e da docência? Mais especificamente, não coloca a formação ética 
como uma função esperada da escola e da docência? Questões urgentes para a pesquisa, a reflexão teórica e para os currículos de formação de pedagogia e licenciatura.

\section{A RETOMADA DA SEGREGAÇÃO SOCIAL E RACIAL}

Tentemos aproximar-nos da descrença em que o humano é viável. Uma das manifestações atuais da descrença na viabilidade do humano está posta na retomada da segregação social e racial. Retomada porque sempre acompanhou a nossa história a segregação dos coletivos sociais, trabalhadores, empobrecidos, e de maneira particular a segregação dos coletivos sociais negros, indígenas, mulheres. Desde a colonização, essa história nos acompanha e não é superada na República e na Democracia. Segregação que se estrutura nas relações sociais, nos padrões de poder-dominação, apropriação-expropriação do trabalho, da justiça, da renda, da terra, do solo urbano, da saúde, do conhecimento etc.

Constante e persistente segregação social e racial que acompanha a tímida afirmação de nosso sistema educacional, sobretudo segregação da escola pública e dos seus profissionais tão segregados quanto o direito à educação dos coletivos sociais, raciais, trabalhadores empobrecidos, mantidos à margem da cidadania, da humanidade e da justiça.

Se essa história vem de longe e persiste, o que tem de novo? Por que falar em nova segregação social e racial? A novidade cruel está em que os segregados, como pobres, negros, são jovens, adolescentes e crianças. E ainda mais cruel: segregados porque foram assim catalogados pelos representantes do poder, pela mídia, pela justiça e pela opinião pública como violentos, infratores, ameaçadores da ordem. Extermináveis. Entregues à justiça penal (ARROYO, 2015a).

Segregação social e racial que se contrapõe aos avanços no reconhecimento dos direitos e se legitima como reação ao lento e tenso reconhecimento político da infância-adolescência como tempos de direitos no Estatuto da Infância-Adolescência. Legitima-se como reação a tantas lutas das famílias, das mulheres trabalhadoras pobres, negras, pelo direito de seus filhos à escola como lugar de proteção, de vida, de um digno, justo e humano viver. Tanto o ECA como a diversidade de movimentos sociais populares pelos direitos das crianças, dos adolescentes e jovens populares reconheciam seu direito à educação. Os reconheciam sujeitos de direitos humanos. Educáveis. Humanizáveis. As famílias de trabalhadores, as mulheres, mães, sobretudo, lutaram pela direito à escola confiantes nos seus profissionais e nas suas artes de proteger essas infâncias-adolescências e de oferecer-lhes uma experiência de dignidade, justiça, educação e humanização.

A história da lenta e tensa afirmação da nossa escola pública e de seus profissionais fazem parte deste tenso e 
lento reconhecimento dessas crianças, adolescentes e jovens pobres, negros, populares que têm direito também a processos de educação, humanização, formação humana plena nas escolas se acompanhados por educadores(as).

Os tempos são outros. Estamos diante de uma nova segregação social e racial desses jovens, adolescentes, crianças, e como pesquisadores, formuladores de políticas, como educadores(as), somos obrigados a nos deixar interrogar: chegamos ao final de uma era de reconhecimento de que o humano é viável? Esses seres, coletivos humanos, são humanos, educáveis, humanizáveis como a pedagogia acreditou desde suas origens? Chegamos ao fim de uma era de lutas e de políticas públicas pelo direito de todo cidadão à educação, à formação humana plena? Que indagações traz para a pesquisa do pensamento pedagógico essa legitimada segregação social e racial?

Alguns pontos merecem destaque.

Primeiro, a segregação se legitima em uma visão extremamente inferiorizada dos outros. Visão que é consubstancial aos padrões classistas, sexistas, racistas de poder-dominação-subalternização que são repostos na agenda política nacional. Uma segregação histórica sempre legitimada em pensar os outros - indígenas, negros, quilombolas, camponeses, trabalhadores como inferiores em racionalidade, em moralidade, em valores. Uma segregação marcada por uma suspensão política da ética por pensá-los inferiores como sujeitos éticos. "As classes perigosas". Ameaçadoras. Imorais.

Os argumentos que legitimam - ao menos no decurso - a redução da maioridade penal e a entrega de jovens, adolescentes, crianças, pobres, negros à justiça penal ou ao extermínio é serem violentos, sem valores de ordem, disciplina, não só na cidade, mas nas escolas. Ser delinquentes, logo extermináveis. Não são os adultos, não é a sociedade que os violenta. São esses jovens, adolescentes, crianças, os violentos. Não os violentados. Análises que inocentam a sociedade, as relações sociais, econômicas, políticas e culpam as vítimas. Os vitimados. Análises que inocentam o Estado, a justiça e os órgãos de repressão. A repressão policial e as condenações da justiça e do Congresso Nacional vêm aumentando contra esses jovens, adolescentes, crianças em nome da defesa moral da ordem social que legitima prender e eliminar centenas de milhares sob o pretexto de uma guerra contra o tráfico de drogas e contra a delinquência infanto-juvenil. (IPEA; WAISELFISZ, 2014; IBGE; PNAD, 2011).

A prisão passou a ser o lugar na nova administração da pobreza (WACQUANT, 2008). Os ilegalismos populares nas tramas da cidade redefinem e reforçam os controles das relações de poder (TELLES, 2011). Nessa tão destacada fratura social e urbana, as vítimas preferidas têm sido os adolescentes e jovens (TAKEUTI, 2002). As ciências sociais, os estudos de sociologia urbana vêm focando a sociologia do crime e da violência urbana (MISSE, 2006). 
Os profissionais das escolas públicas que acolhem os jovens, adolescentes e crianças das periferias urbanas lidam com essas violências urbanas, com essas fraturas sociais, com esses ilegalismos e com os refinados controles repressivos do poder. Essa centralidade dada às violências padecidas por esses jovens, adolescentes e até crianças deveriam ser centrais nos currículos de formação docente-pedagógica e deveriam ser centrais no direito de esses educandos(as) saberem-se.

Haverá espaço nos novos Currículos de Bases Nacionais Comuns para esses jovens, adolescentes, crianças, criminalizados porque são pobres, negros? Talvez não, porque a ênfase no comum, no nacional, não deixe espaço para as diferenças. Ou talvez porque essas outras infâncias, adolescências e seus grupos sociais, raciais, não foram reconhecíveis como membros da nação, da justiça, da cidadania. É extremamente preocupante que em tempos de presença tão destacada na agenda política nacional da criminalização, segregação social, racial dos milhares de educandos os Currículos de Bases Nacionais Comuns os ignorem na agenda política-pedagógica.

Segundo: essa ênfase na delinquência ou na imoralidade dos pobres, negros, trabalhadores desde crianças nos leva a outro ponto - a função social encomendada à escola e à docência.

A ênfase na inferioridade moral dos outros levou, em nossa história, a se encomendar à escola pública e a seus profissionais a função social de moralizar a infância e adolescência populares. As escolas das primeiras letras, como hoje de letramento, não passaram de inculcação dos primeiros ensinamentos morais, de criar hábitos de convívio, de trabalho, de disciplina, de ordem. O ensino primário em conhecimentos era farto em bons conselhos moralizantes das crianças pobres, dos negros que lentamente ocupavam os bancos das escolas. Para as elites, a função encomendada da escola pública não era e não é esclarecer, ilustrar as mentes dos filhos(as) do povo, mas moralizá-los.

A nova segregação social e racial repõe essa função social moralizante da escola pública. A velha frase moralizante: abramos uma escola e fecharemos uma cadeia sintetizava essa visão do povo delinquente, imoral por origem, classe, raça. Imoralidade que o destinava à cadeia, mas que uma escola desde que o moralizasse poderia reverter esse destino. A defesa das elites políticas, de imprensa e de 80\% da população de que o lugar desses jovens, adolescentes, crianças é na cadeia, e não na escola, é uma proclamação da visão de que a escola e seus profissionais não deram conta nem de moralizá-los. A escola pública e suas políticas teriam fracassado na função social que as elites lhe encomendaram: não instruir os filhos do povo, mas moralizá-los. Inculca-lhes valores de ordem, de trabalho, de respeito à propriedade alheia.

Por aí chegamos a questões que exigem ser mais aprofundadas: a criminalização moral como justificativa 
para a segregação social e racial está posta na agenda política e pedagógica. A agenda política que priorizava a inclusão social, racial, é abandonada. As lutas dos grupos sociais marginalizados por direitos, por afirmação como coletivos de saberes, valores, culturas, identidades, por se afirmarem sujeitos políticos e de políticas de direitos a terra, teto, cidadania, justiça são condenadas, criminalizadas e reprimidas. Suas lideranças, exterminadas.

Uma nova segregação social e racial que se afirma no extermínio de jovens negros pela justiça e pelos aparatos de repressão nos Estados Unidos (ALEXANDER, 2014), que se afirma aqui: em cada fim de semana, a percentagem de jovens exterminados é altíssima, e de cada três, dois são negros. Uma nova segregação social e racial posta na Europa da ilustração, da igualdade e fraternidade diante dos milhares de imigrantes negros, muçulmanos, vítimas da globalização da pobreza e dos conflitos gestados e consentidos pelas elites políticas europeias e dos Estados Unidos e pela globalização econômica. Uma segregação social, racial, de que são as vítimas mais frágeis as crianças.

\section{REPONDO A MORALIZAÇÃO NA AGENDA POLÍTICA E PEDAGÓGICA?}

Avancemos para a segunda parte de nossa análise: se essa segregação social e racial está posta na agenda política global e nacional, que interrogações ela traz para a agenda política e pedagógica? Para aproximar-nos dessa questão, lembremos que na agenda política das elites a segregação social e racial se legitima na criminalização moral dos jovens, adolescentes, das crianças e de seus coletivos sociais e raciais. Essa criminalização moral não apenas legitima a agenda política de seu extermínio, da sua entrega à justiça penal, mas legitima a condenação da escola pública e de seus profissionais por não terem dado conta de moralizá-los nos valores da ordem social, do cidadão, nos valores de trabalho, de respeito à propriedade alheia.

A criminalização moral dessas infâncias e adolescências traz um apelo a que a escola tente retomar sua função moralizadora dos imorais. Na medida em que a segregação social e racial tenta se legitimar na criminalização moral dos segregados, repõe na agenda política e pedagógica a falta de moralidade dos segregados ou repõe o fracasso das instituições educativas às quais foi encomendada sua moralização. A segregação social e racial é legitimada na condenação, porque sem valores de ordem, de trabalho, de respeito à propriedade, ao convívio social repõe com centralidade a função moralizadora esperada e não cumprida da escola.

Esse apelar para a escola, para a sua função moralizadora do povo, "das classes perigosas" desde a infância, tem sido uma constante em nossa história. No regime autoritário, já foi obrigatória a formação moral e cívica. A ética entrou como um tema transversal nos PCN e entra nos 
currículos de educação básica como aulas de religião ou de ética. Entretanto, as elites políticas, a mídia, a opinião pública estão a nos dizer que essa função moralizadora não tem conseguido moralizar os jovens, adolescentes, as crianças, os pobres, negros, nem na própria escola, e menos ainda a sociedade.

A questão que se coloca à agenda política e pedagógica é que resposta e que reação é possível a essa condenação da escola, da docência de não ter dado conta da formação moral, ética dessas crianças e adolescências. As reações apontam para uma reação ética-política da escola e de seus profissionais no sentido de defender essas infâncias, adolescências criminalizadas, reagir à sua criminalização moral. Ao menos não somar com a criminalização moral da infância e adolescência populares como violentos, sem valores de disciplina, trabalho, nas escolas.

\section{A REAFIRMAĈ̃O POLÍTICA DA ÉTICA NA FORMAÇÃO HUMANA}

As repostas que vêm das escolas e de seus profissionais estão indo além: reafirmar que a função da escola, da pedagogia, da docência, não é moralizar, mas garantir processos de formação ética como componente do direito à formação humana plena, porque, como profissionais da educação, acreditam na educabilidade dessas infâncias-adolescências. Acreditam que o humano é viável.

As instituições e os profissionais que têm como ofício ensinar-educar vão sentindo necessidade de reflexões e de compromissos no campo da afirmação política da ética na formação. Não apenas das escolas, mas de todas as instituições, os próprios adolescentes e jovens nas ruas esperam dar centralidade à ética: ética na política, na economia e no Estado. Se faltam convicções, será necessária uma ética da convicção que nos leve a uma ética da responsabilidade nos campos do poder, do trato do público e também do privado, nos convívios, no trabalho profissional... Nas escolas e universidades, coletivos de professores(as) e educandos(as) investem em oficinas, temas geradores, projetos sobre valores, ética, formação humana, se contrapondo à criminalização moral e à segregação social e racial dos educandos(as).

Os projetos podem representar um esforço teórico e um clima prático que tenha o respaldo de todo o coletivo da instituição escolar. Uma tarefa como esta não pode ser vista como um capricho de alguns mestres. Nem pode ser reduzida a uma temática a ser abordada no modelo de aula ou de transversal. A ética é uma das preocupações mais antigas da reflexão pedagógica e do conhecimento. Colocá-la no plano do conhecimento, da herança cultural, será uma forma mais séria de tratá-la. Porém, não como um conhecimento externo a nós, mas como uma vivência do nós. Como um legado de compromissos coletivos e de convicções pessoais, sociais e políticas e de compromissos 
dos próprios educandos, adolescentes e jovens. Frente à negação política da ética que legitima a criminalização dos jovens, adolescentes e até das crianças pobres, negras, a função da escola, dos seus profissionais e das políticas será repor a afirmação política da ética (ZIZEK, 2005; 2009).

Assumir a formação ética é colocar-nos em um tempo político de prestar contas. Se nos propomos a trabalhar os padrões de conduta, não será, pois, suficiente tratar a ética como um tema de conhecimento, mas como um legado de responsabilidades sociais e políticas. Nessa preocupação, por tratar a ética no terreno das responsabilidades sociais e políticas, poderemos ir além de focalizar as condutas individuais dos alunos e mestres e trabalhar, por exemplo, as responsabilidades sociais, éticas das ciências e das técnicas. A ética na história de cada área do conhecimento de que somos profissionais até a ausência ou a centralidade da ética na formação docente e pedagógica.

Como trabalhar a ética em oficinas ou temas geradores sem cair em posturas moralizantes? Alguns coletivos docentes das áreas tentam aproximar distâncias entre os mundos humanísticos e tecnocientífico. Questões como a ética medioambiental, a bioética, ética e tecnologia, ética e ciências da vida, ética e apropriação da terra, da justiça etc. são campos atraentes para trabalhar com adolescentes, jovens e adultos. São eles que exigem ética na política, no público, ética na cidade. Podemos trazer o debate com artigos, notícias ou textos as relações entre ética e trabalho e o comportamento ético-empresarial, ético-politico, ético-financeiro, ética e produção de alimentos ou de remédios, ética e fome, desemprego, violência, exploração da infância, ética na sociedade da informação, na mídia etc.

Os movimentos sociais e juvenis têm mostrado sensibilidade e preocupação com as dimensões éticas de todos esses campos da vida social. Será fácil encontrar nos educandos(as) e educadores(as) sensibilidades para o trato pedagógico dessas responsabilidades sociais. Este poderá ser o foco a destacar: a ética das responsabilidades sociais, econômicas, políticas, técnicas, científicas. Pedagógicas. Como tratam os processos de deformação-desumanização? Que coletivos sociais, raciais, são afetados pelas responsabilidades e irresponsabilidades sociais? Em outros termos: começar por destacar e aprofundar nas dimensões antiéticas das relações sociais, políticas, econômicas que tanto condicionam o indigno sobreviver dos educandos e até dos professores(as).

\section{DESCONSTRUIR CONTRAVALORES, EDUCANDO EM VALORES?}

Esta tem sido a função esperada da escola: desconstruir os supostos contravalores com que chegam os educandos e educá-los em valores. Será necessário ir além de trabalhar na consciência dos contravalores que condicionam o seu viver. Educar nos valores humanos não é o mesmo 
que desconstruir contravalores. Os processos de desumanização a que são submetidos tantos seres humanos desde crianças não caracterizam uma situação de falta de valores pessoais ou familiares que através de projetos de formação ética poderão ser adquiridos. A desumanização é uma negativa formação. É um mal. É um processo de deformação ética. Não é uma fatalidade que castigue tantos seres humanos, nem é uma opção pessoal por contravalores a serem reeducados através de reconhecer os bons valores. Algo assim como a infelicidade não é mera negação da felicidade! É um mal, um processo de múltiplas experiências de dor, frustração. De infelicidade. Consequentemente, os projetos têm de ir além de ensinar os bons valores, de inventar didáticas de que aqueles valores que pensamos não os aprenderam na família, na rua, na sobrevivência ou na droga e na violência, os aprendam na escola.

As escolas tendem a ajudar a entender os contravalores estruturantes das relações sociais e políticas que os segregam e desumanizam. Entender os processos de deformação. Tratar profissionalmente processos brutais de deformação exige muito mais cuidado, conhecimentos e artes. Exige superar ingênuas classificações entre os alunos que aprenderam os bons valores e alunos que não os aprenderam, como classificamos os que aprenderam as matemáticas ou a biologia e os que não. As lógicas ingênuas que aplicamos às aprendizagens e não aprendizagens dos conteúdos resultam muito mais ingênuas quando aplicadas à formação ética e a educar em valores.

Tratar processos brutais de deformação ética inerentes às relações de opressão é muito mais complexo do que recuperar ritmos lentos de aprendizagem de conteúdos. Como tratá-los? Para começar, tentar reconhecer a peculiaridade desses processos de deformação moral. Assumir que estamos tocando processos diversificados de desumanização, miséria, mas onde não faltam processos de grandeza humana até em situações brutais de desumanização. Em vidas em que tudo revela contravalores, ver ou tentar descobrir brotos de valores que são Mais Valores porque são submetidos a tantos contravalores. Não ficar em visões sombrias de perversão moral em que são enredados desde crianças. A violência, a droga, a prostituição, o ódio, o salve-se quem puder disputam vontades, opções e liberdades, solidariedades, dignidades. Essa é a disputa ética a ser captada e em que as trajetórias de tantos educandos se desenrolam. Não rotular os alunos entre os bons e os maus, os dignos e os viciados, mas vê-los como personagens éticos em conflitos éticos demasiado dramáticos para o seu desenvolvimento humano e moral. Acreditar que nesses brutais processos de desumanização a que são submetidos o humano é viável.

Se por formação ética entendemos que toda criança, adolescente ou jovem adira à ordem moral de um mundo que os condena à fome, à exclusão, à segregação, não será nada fácil nosso intento. Talvez o mais denso nesses 
projetos que se atrevem a trabalhar com a ética seja ouvir dessas crianças, adolescentes e jovens as críticas que vem de suas vivências nessa ordem moral (imoral). Questionar essa ordem, trazer exemplos de pessoas e grupos que a condenam por imoral e que lutam por outra ordem inspirada em outra moral. Impressiona com que facilidade as escolas passaram a catalogar entre os personagens indignos crianças e adolescentes supostamente portadores de condutas indesejáveis. Classificam-se como indesejáveis para o fazer educativo exatamente aqueles que a sociedade lança na luta pela sobrevivência em ambientes carentes de referências morais.

Para um educador, seria uma postura ética inicial indagar como sobrevivem em situações tão desumanizantes e, sobretudo, como preservam sua humanidade a ponto de voltar cada dia à procura do saber e da educação. Indagar também pelas sequelas que deixa em sua formação ética a experiência tão prematura de processos brutais de desumanização. Nos cursos de formação, deveria ser dada centralidade a entender desde o pensamento educativo as catastróficas consequências para a formação ética, cultural e humana, produzidas pela pobreza, fome, marginalização das crianças, dos adolescentes, alunos das escolas populares. Dezessete milhões de crianças e adolescentes levam cada dia às escolas as vivências desumanizantes de ser condenados com suas famílias e sobreviver na pobreza extrema. Os cursos de formação nas licenciaturas e na pedagogia fornecem pautas teóricas e práticas para compreender essas catastróficas consequências para nelas intervir como educadores(as)? Quando o mal se banaliza, que condutas esperar de crianças, adolescentes e jovens expostos a essa banalização? Os cursos de formação poderiam cultivar nos profissionais da educação desses educandos a capacidade de ler com perspicácia e profundidade ética essas perversas consequências antiéticas.

\section{ESCOLA ABERTA A UM DEBATE ÉTICO}

Os adolescentes e jovens se manifestam exigindo ética na política, ética nas instituições, porém são condenados como sem valores. Esse debate ético está posto na sociedade e nas escolas pelos próprios jovens e adolescentes. Os projetos de formação ética vêm aumentando em coletivos de educadores(as) e conseguindo impregnar, contagiar até os mais cotidianos rituais da escola e abri-los a um debate ético. Por exemplo: o ritual da avaliação, julgamento e reprovação não deixa fissuras para qualquer questionamento moral. Será conveniente e necessário planejar oficinas, temas de estudo sobre as dimensões éticas e antiéticas dos rituais de avaliação. Não reproduzem rituais tão próximos de avaliação-condenação das crianças, dos adolescentes e jovens populares pela sociedade? Faltam ou resistimos a inventar pautas morais para avaliar, por exemplo, esse perverso ritual da avaliação, do julgamento, da reprovação e 
da condenação. Cada escola e cada professor é livre para impor suas pautas.

Enquanto o fazer cotidiano da escola e da docência não se abrirem a um debate ético, os projetos de formação ética ficarão na periferia. Os processos de avaliação são estruturantes da escola, de ensinar-aprender, do trabalho docente-discente. Impõe-se olhar esses processos tão estruturantes como um olhar ético. Que valores-contravalores legitimam os processos de avaliação, julgamento, reprovação, condenação? Que crianças, adolescentes, jovens são condenados, segregados? Questões de extrema relevância ética. O grave das antiéticas avaliações é que não avaliam apenas níveis de conhecimento, mas são avaliações dos valores-contravalores com que se processam as aprendizagens. Sem cabeça para as letras, com problemas de aprendizagem, sem assiduidade, sem dedicação ao estudo, ao trabalho, sem disciplina; logo, reprovável. A cultura escolar da reprovação se alimenta mais da reprovação em valores do que em níveis de conhecimento. A mesma lógica com que a sociedade reprova essas crianças, esses adolescentes como sem valores.

A direção assumida pelos projetos sobre formação ética vai depender em grande parte da visão que tenhamos dos educandos como sujeitos éticos. As reprovações se justificam em visões negativas. Moralizantes. Se os vemos carentes ou à procura de referentes morais ou se os vemos como indolentes, a tendência será catequizá-los, dar-lhes conselhos. Reprová-los. Se os vemos como vítimas de uma sociedade sem referentes éticos, mas à procura desses referentes para suas dramáticas escolhas, a tendência será ir construindo junto com eles esses referentes, fortalecer sua capacidade de escolha, de agirem com liberdade. Essa postura pedagógica será muito mais complexa do que a primeira.

Diante da segregação moral posta na sociedade, as escolas são pressionadas a desqualificar as condutas dos alunos pelas motivações supostamente torpes que as movem. Mas há docentes e gestores que se perguntam por que essas condutas são um dado cada vez mais presente na sociedade e nas escolas. Dados ou fatos que estão se impondo e criando um desafio e um caminho sem volta para o pensar e fazer educativos. Lamentáveis condutas, sem dúvida, feridas da sociedade expostas nos corpos inocentes de crianças e adolescentes. Mas é assim, conscientes de que se abrem feridas, que as instituições se redefinem. A crise de valores, sobretudo quando afeta crianças e adolescentes, terminará interrogando a ética da docência e da escola e até a ética dos conhecimentos, dos currículos e do material didático. Interrogando a ética da avaliação.

Na medida em que a escola se abrir a um debate ético sobre a educabilidade das crianças, dos adolescentes e jovens populares tão criminalizados, poderá exigir da sociedade e do Estado que se abram a esse debate ético e acreditem na educabilidade desses jovens e não os criminalize. 


\section{ATÉ A INFÂNCIA ENTRE O BEM E O MAL?}

Na medida em que se avança nessas questões, chegaremos a um campo nuclear na formação do sujeito ético. Não só a sociedade, mas a escola é também um espaço, um palco, no qual se desdobra o eterno duelo entre o bem e o mal. Um filme que nunca sairá de cartaz retomado como o filme fiel de nossa sociedade. A pedagogia imaginou que, por tratar com crianças, poderia construir um espaço isento desse duelo. Nessa ingenuidade, é lógico que nos escandalize ver que até nas escolas e até nas infâncias se trava uma batalha entre o bem e a maldade. As escolas se surpreendem como se essas crianças viessem de outros mundos e logo as encaixam em suas tradicionais polarizações: os bons e os maus. Polarizações moralizantes nos mesmos moldes das tradicionais polarizações intelectuais: os inteligentes e os ignorantes, os bem-sucedidos e os fracassados, os aprovados e reprovados. Agora os moralmente aprovados e os reprovados por imorais.

Tratar a condição humana, inclusive na infância e na adolescência, como um eterno duelo entre o bem e o mal nos ajudaria a superar espantos e, sobretudo, velhos julgamentos e classificações tão polarizadas. Ver até as crianças envolvidas nesse duelo deveria levar-nos a uma reflexão fecunda sobre a formação ética desde a infância. As escolas parecem preferir trabalhar com personagens essencialmente planos, sem fissuras nem nódulos. Nessa visão de vidas planas, não cabe qualquer exercício de escolha, de assumir riscos. Não cabe o humano exercício da liberdade. Não cabe a formação de sujeitos éticos. Às escolas, até à educação na infância, chegam infâncias quebradas (ARROYO, 2012a). Chegam infâncias reais que quebram imaginários idealizados de crianças. A pedagogia prefere ver a infância como incontaminada nesse duelo entre o bem e o mal. As próprias crianças desconstroem essa visão ingênua e nos mostram que desde bem cedo são obrigadas a entrar nesse duelo. São expostas a tensos exercícios morais de ser crianças (ARROYO, 2012b; 2015b). Milhares de crianças e adolescentes submetidos ao intrincado fenômeno da exploração sexual comercial que consome seus corpos e destrói suas identidades infantis e juvenis (VIELLA; VENDRAMINI, 2012).

O duelo dessas crianças populares entre o bem e o mal é uma voz através da qual nos falam os setores populares do perverso e dramático duelo imoral a que lhes submete a miséria, a fome, o desemprego, a sobrevivência a qualquer custo. Duelo de valores, tradições, culturas, arraigados na moral popular sendo levados ao limite pela imoralidade social, política e econômica. As crianças apenas leem na cartilha de seu grupo social e da desordem social. A nós cabe escutar essas falas e deixar-nos arrastar pela força do rio de suas palavras e gestos. Eles sabem que o pior não tem fundo. E a exploração imoral a que são submetidos não aponta qualquer final feliz. Têm de aprender que são condenados 
a vidas desperdiçadas (BAUMAN, 2013). A nós, profissionais da educação, cabe estarmos avergonhados da imoralidade com que a sociedade trata o povo e a sua infância. A nós, cabe denunciar essa imoralidade social, essas vidas desperdiçadas, condenar à injustiça com que essas infâncias são tratadas pela imoralidade social.

Nesse duelo, debate-se a infância e a adolescência, os jovens e adultos populares que a sociedade entrega às escolas para moralizá-los. Nesse duelo se debatem as escolas e seus profissionais para reconhecê-los educáveis.

A questão com que nos defrontamos é que a moral é possível em jovens, adolescentes e crianças acuados num círculo fechado comum: a comida, a fome, o trabalho, a sobrevivência. Gente que desde crianças resiste e se empenha e sonha em sair desse círculo fechado, mas aos que a realidade nunca deixa de lembrar qual é seu lugar - esse círculo. Contudo, tentam fazer escolhas, lutam para sobreviver com honestidade, acumulam pequenas satisfações e amargos desencantos. Mostram-se viáveis como humanos. A postura mais pedagógica será não condená-los e reconhecer que nos limites passam por processos de construção moral marcados pelo paradoxo e a precariedade. A postura mais pedagógica será não somar, mas denunciar a criminalização moralizante a que a sociedade os condena porque são pobres, negros, trabalhadores por sobreviver. Entre a ingenuidade moral e o paradoxo moral, o trato deste será sempre mais pedagógico. Os dramas morais que a infância traz às escolas podem resultar-nos pesados, porém podem representar um ar fresco renovador, no trato pedagógico dos valores e da ética.

Nesses tempos da criminalização e segregação social e racial das crianças, dos adolescentes e jovens populares, nos oferecem a Base Nacional Comum Curricular (MEC, 2015). É preocupante que essas BNC não tenham como referente esses educandos(as) reais, criminalizados. Ignora-se o aumento de sua segregação social, de classe, de famílias de trabalhadores empobrecidos. Ignora-se o aumento de sua segregação-criminalização racial. A histórica segregação de classe, social, racial, de gênero, de lugar (favelas, vilas, conglomerados) que chega às escolas públicas nem é nomeada.

As próprias tensões sociais, raciais, de gênero, orientação social com que os docentes-educadores(as) e os educandos(as) se debatem nas escolas, na cidade e na sociedade não são nomeadas e se recomenda piedosamente "[...] priorizar e cultivar o convívio afetivo e social, fazer-se respeitar e promover o respeito ao outro, para que sejam apreciados sem discriminação por etnia, origem, idade, gênero, condição física ou social, convicções e credos" (MEC, 2015, p. 8). Seguem mais outros princípios orientadores da BNC curricular.

A pergunta se impõe: quais as virtualidades "orientadoras" desses princípios e dessas BNC para milhares de docentes-educadores-gestores(as) que trabalham nas escolas públicas em que chegam infâncias quebradas, 
adolescentes e jovens segregados, ameaçados, violentados, obrigados a "ganhar a vida, ganhar a morte" (OLIVEIRA, 2011)? Que buscam na escola um tempo, espaço de um digno, justo, humano viver (ARROYO, 2012c)?

A impressão que deixam esses princípios orientadores da BNC é que esses jovens, adolescentes, crianças segregados, criminalizados não fazem parte do Comum, do Nacional. Que continuam à margem das Bases Nacionais Comuns Curriculares porque estão à margem da ordem nacional, da justiça nacional, das políticas sociais, educativas, nacionais. A própria opção por Bases Nacionais Comuns deixa explícito que os outros, os diferentes segregados como desiguais, criminalizados porque são diferentes, trabalhadores, pobres, negros, não cabem no comum, nem no nacional. Volta a pergunta: por que tamanha insensibilidade para a criminalização dessas crianças, adolescentes, jovens tão destacada na agenda social e política?

\section{NAS ENCRUZILHADAS SOMOS OBRIGADOS A OPTAR}

As escolas públicas e seus profissionais não ignoram essa realidade e são levados a politizar os valores-contravalores com que a formação ética nos defronta: que possibilidades têm os educandos(as) de opções, de exercícios de liberdade real? Em que encruzilhadas são obrigados a optar? Este é um dos princípios da ética, porém milhões de humanos estão em encruzilhadas e sem qualquer liberdade de poder optar. Até crianças, adolescentes ou jovens nos limites da sobrevivência mais imediata, que liberdade têm de optar? Conseguem controlar o seu destino histórico?

Interrogações presentes no pensamento social, no cinema e nas artes. Interrogações que vão chegando às escolas e à docência questionando a crença humanista da tendência do ser humano para sua superação e seu aperfeiçoamento. Se estamos em um momento de recessão humana de dúvida de que o humano é viável, que lugar há para a pedagogia? Acompanhar essa recessão? Desacreditar de que o humano é viável? Manter imagens angelicais de infância? Lembro-me do comentário de um professor: "ao longo do percurso escolar as condutas dos alunos vão piorando, quanto mais crescem e experimentam a vida, mais desumanos se tornam". Poderíamos pensar que um adolescente ou jovem, na medida em que avança na vida, vai entrando nesse processo de recessão de valores? Vai tendo de acompanhar a recessão humana, ética da humanidade? Vai mostrando não ser viável como humano? Que resta para nós, que temos por ofício acompanhar esses processos? Quando essas perguntas invadem a docência e as escolas, templos das crenças humanistas do progresso humano, da superação e do desenvolvimento das potencialidades humanas, alguma coisa estremece nas culturas pedagógicas e docentes.

Acompanhar a infância é acompanhar um falso amanhecer? Uma humanização incerta? Não por acaso, as 
escolas relutam em assumir como sua tarefa a formação ética dos educandos(as). Talvez porque o campo da ética está em recesso na sociedade, o que deixa nosso ofício sem referências. O campo do conhecimento e das ciências ainda promete avanços atrás de avanços. Surpresas fascinantes a ensinar. As políticas e diretrizes curriculares preferem ignorá-lo ou optam por privilegiar as Bases Comuns Nacionais nos currículos, preferem a formação docente no domínio de ensinar essas Bases Comuns Nacionais e preferem Avaliações Comuns Nacionais para avaliar o que aprender. Haverá lugar nessas políticas para as interrogações humanas, éticas vividas por educandos(as) e educadores(as)? Os noticiários de cada noite sobre crimes, violências, invasões por cobiça, crianças sem rumo, mortes de adolescentes-jovens... nem mais nos surpreendem, apenas revelam crise de paradigmas morais? A recessão ética? A tendência será esquivar essas questões, abandonar nosso oficio de educar para a liberdade, uma vez que à maioria das crianças, dos adolescentes e jovens com que trabalhamos não lhes é dado fazer escolhas, ou tem de fazer escolhas nos limites mais estreitos da sobrevivência.

Se, como tentam nos convencer, o mal não pode se exterminado, se ele avança mais do que o bem, que papel cabe às escolas? Pode restar a denúncia da imoralidade que autoriza tantas atrocidades, padecidas inclusive pelos alunos em nome do mito do progresso moral. Abrir os debates nas escolas e os cursos de formação a essas cruciais interrogações já é um avanço. Reconhecer, ao menos, que convivemos com crianças, adolescentes, jovens ou adultos que se debatem com esses impasses humanos, éticos e pedagógicos. Há lugar para reconhecimentos aprofundados nos currículos de formação e de educação básica para esses impasses humanos que nos afetam e afetam a crianças, adolescentes, jovens com que trabalhamos? A ênfase no que ensinar-aprender-avaliar tão dominante nas políticas curriculares, de formação docente e de avaliação, está a nos dizer que não há lugar para esses impasses que ignoram o viver real, o sobreviver dos educandos, que ignoram a criminalização moral da nova segregação social e racial. Tempos desfavoráveis à formação ética? Acompanha-nos a hipótese de que esses impasses estão provocando nas escolas e nos seus profissionais a reafirmação política da formação ética.

\section{HÁ RESERVAS MORAIS NA CULTURA POPULAR?}

Diante desses limites, a tendência pode ser ignorar essas infâncias-adolescências e até duvidar sobre a viabilidade do humano. Mas há educadores(as) que não ignoram essas infâncias e descobrem nesses limites brotos de humanidade. Os novos currículos de Bases Comuns Nacionais terão um mínimo de sensibilidade para esses impasses humanos vividos por educandos(as) e educadores(as)? Uma professora apontava a saída nos limites desses 
contextos tão adversos: "quando escuto as notícias tão negativas na TV ou quando as leio nos jornais me faz bem lembrar de tantos gestos de humanidade, dedicação, cuidado que vejo cada dia nas mães pobres que levam e recolhem seus filhos na escola”. Só o olhar docente-educador para essas sensibilidades tão escassas no olhar tecnicista, gestor, avaliador de domínios de aprendizagem dos conteúdos das Bases Comuns Nacionais.

Talvez seja essa a saída pedagógica: lembrar os valores presentes na longa tradição popular e nela descobrir indícios de que ainda há valores reservados que dão forma à identidade e cultura populares, que alargam o significado de seu direito à formação humana. Com esse olhar, as dúvidas sobre a viabilidade do humano não se dissipam, mas se tornam menos simplificadas. Porém, com todo cuidado para não cairmos em celebrações triunfais do passado e presente dessa reserva moral. Evitar simplificações que destacam os dramas morais vividos pelos pobres, deserdados e oprimidos. Evitar o engano de que a moral popular seja uma dádiva da escola, instituição que levaria aos filhos do povo os valores das elites cultivadas. Assim como evitar a presunção de que o povo tenha uma espécie da moral inata a ser cultuada.

A sensibilidade pedagógica dos docentes-educadores(as) nas escolas públicas percebe que a formação moral do povo é complexa e tão dramática quanto os limites a que são submetidos na luta pela sobrevivência, pelo teto, pelo trabalho, pela terra, pela sua identidade e pela sua memória. Difícil conduzir um projeto de formação ética da infância, adolescência e juventude populares sem rever visões estereotipadas da moral popular. Por exemplo, se mantemos a visão moral negativa ou a visão exótica a que é reduzida a cultura popular, ficaremos presos nesses rótulos, inclusive na hora de entender as condutas das crianças ou jovens populares. Se reduzimos o povo a um bando de crianças primitivas, próximas do "homem bom" rousseauniano, não entenderemos seus dramas e tensões morais. Terminaremos condenando crianças ou jovens que não se encaixarem nesses rótulos estereotipados de "bom selvagem". Não chegaremos a perceber que essas crianças e jovens se debatem com escolhas morais como todo ser humano, mas em limites sub-humanos. Essa é uma diferença radical entre as infâncias-adolescências que frequentaram por décadas as escolas e as novas que lutam por chegar das vilas e dos campos.

Noções preconcebidas da moral popular, seja por visões exóticas ou negativas, em pouco ajudarão a entender a moral dos filhos do povo com que convivemos. Como entender a moral popular? Suas raízes se afincam no solo das tradições da moral do trabalho, da agricultura familiar e de sobrevivência, da estreita relação com a natureza, com a centralidade da família e do grupo nos processos de sociabilidade, de produção e defesa. Uma moral inseparável do contexto mais imediato. Uma moral generosa, inclusiva do 
imigrante, do mais necessitado. Uma moral aprendida nas celebrações coletivas da memória, dos fatos e das histórias com sua "moral da história". Uma moral enraizada nas suas referências culturais e nos seus saberes e leituras de mundo. Moral, valores, saberes, leituras, culturas entrelaçadas como uma síntese. Aproximar-nos da moral popular supõe reeducação de nossos olhares sobre o povo e sobre as infâncias-adolescências com que trabalhamos nas escolas.

\section{ASSUMIR QUE O HUMANO É VIÁVEL}

Diante da criminalização moral das crianças, dos adolescentes e jovens como justificativa para sua segregação social e racial, somos obrigados a ter uma postura profissional nova: assumir que o humano é viável. Coletivos de professores-educadores(as) assumem essa postura e põem em prática estratégias múltiplas. Lembro-me de oficinas em que a base do estudo eram filmes como Central do Brasil, Vidas Secas, O Círculo, o Balão Branco, do cineasta iraniano Jafar Panahi: na véspera do ano novo, uma garota convence sua mãe a lhe dar dinheiro para comprar um peixinho dourado e, no caminho da loja, vários adultos tentam tirar vantagem de sua inocência - ela fica sem o dinheiro e sua busca se transforma numa jornada moral cheia de obstáculos.

Podemos examinar rostos e corpos de crianças nas fotografias dos jornais, da Unicef, Sebastião Salgado, e captar seres acuados, de olhares interrogantes sobre o seu viver e sobre a sociedade... As artes, a literatura, continuam acreditando que o homem é viável e denunciam os processos sociais que tornam o humano inviável.

Os projetos de formação ética ficam por vezes meio desfocados ou caem na formação de condutas com viés um tanto moralizante. Outros se limitam a inculcar condutas de integração dos alunos na ordem e disciplina escolar. Mas há projetos que vinculam a formação ética com projetos de sociedade e ao menos de escola, por exemplo, de uma sociedade sem segregação e de uma escola sem reprovações, mais livre e igualitária, em que o gozo das liberdades seja real para todos. Comprometer as crianças, os adolescentes, jovens ou adultos educandos com esses projetos e ideais éticos seria uma forma eficaz de formação ética. Ao menos amarrar essa formação a um conhecimento do que há de injusto na sociedade e nas favelas, no desemprego e até do que há de injusto nas escolas. Sobretudo, amarrar a um conhecimento do que há de valores nas lutas pela justiça, igualdade, liberdades nos movimentos sociais, no movimento juvenil e na própria escola. Em todos esses processos, há valores e contravalores a serem explicitados e debatidos com os educandos, o que se constituirá em uma dinâmica formadora. Haverá lugar para esses conhecimentos nas Bases Nacionais Comuns e nas novas diretrizes da formação docente?

Um exercício bastante formador é dedicar um dia de estudo, ou uma oficina para colocar em comum o que 
sabemos das crianças, dos adolescentes ou jovens "com problemas de conduta". Tentar levar a esses dias de reflexão as trajetórias humanas-desumanas desses educandos. Lembro-me de uma professora que repetia sua surpresa com um aluno adolescente: "era dos melhores alunos quando ele mesmo me contou estar envolvido na violência. A primeira vez que vi como violenta uma pessoa que tinha visto amável e bem comportada". A maioria dos professores concordaram que vemos alunos violentos como alguém já pronto, como se tivesse nascido com essa marca. Há um estereótipo já feito e aceito. Se é pobre ou negro, logo propenso está a ser violento. É o estereótipo dominante na cultura social racista e que os noticiários da mídia perpetuam como um destino, uma herança.

A surpresa da professora diante de um aluno bom que se mostra violento trouxe uma reflexão sobre o pouco que sabemos desses processos éticos em que tantas crianças, adolescentes e jovens se debatem. Superar atitudes de surpresa diante desses tensos debates éticos vivenciados por tantas crianças-adolescentes e jovens nos obriga a repensar como vemos a formação ética do ser humano. Obriga-nos a repensar os paradigmas epistemológicos com que o pensamento moderno e a pedagogia moderna continuam pensando os outros. A criminalização moral dos outros em nossa história e a nova criminalização social e racial repõem com radicalidade esses paradigmas epistemológicos abissais e sacrificiais dos outros (SANTOS, 2009).

A criminalização moral dessas infâncias-adolescências na sociedade e nas escolas, sua segregação nas avaliações, não interrogam apenas a formação moral, ética nas escolas, mas interrogam com radicalidade a dita formação intelectual. Interrogam a segregação de milhares de educandos(as) por supostos problemas de aprendizagem e de comportamentos.

Ninguém nasce com problemas de comportamento e de aprendizagem. Estamos diante de um ser feito em complicados processos de sociabilidade e socialização. Se preocupados, como educadores(as) em conhecer esses processos, mudaremos nossos julgamentos. Nós nos sentiremos desafiados nas artes de conhecer e acompanhar as contraditórias virtudes e misérias de seres humanos expostos a esses processos de socialização desde crianças, mas também reagindo desde crianças. Nós nos sentiremos situados no cerne da eterna tensão entre o bem e o mal, o progresso e a barbárie, a humanização e a desumanização. Obrigados a entender as relações sociais, econômicas, políticas que desumanizam. Não é esse o lugar onde sempre esteve a educação?

$\mathrm{Na}$ literatura, narrativa, conto, novela, história foram sempre as vidas dos chamados "personagens indignos da história", as mais ricas em matizes humanas e morais. As mais clássicas histórias infanto-juvenis estão carregadas dessas confrontações morais. Nelas, o que cativa são crianças e adolescentes defrontando-se cedo com o bem 
e o mal. O que as torna pedagógicas é, nesses confrontos, aparecerem referentes morais e "asideros" de identidade e liberdade.

A pedagogia conviveu sempre com esses confrontos morais em personagens infantis, adolescentes e juvenis ou adultos. O que muda agora é que esses confrontos não aparecem romanceados em narrativas históricas distantes, mas são confrontos morais e éticos em que os personagens são os próprios educandos(as) com que convivemos nas salas de aula, nas ruas, no noticiário. O que há de diferente é que até as crianças e os adolescentes são criminalizados, entregues à justiça penal ou exterminados porque são pobres e negros. A negação política da ética exposta nessas violências.

O que há de diferente agora é que nas histórias tradicionais o bem sempre triunfava, enquanto que nos confrontos dos personagens concretos, até infantis, nem sempre o mal vence. $\mathrm{O}$ que nos provoca uma dúvida desconcertante para a pedagogia: a formação e a perfectibilidade humana é viável? Inclusive em crianças? Se nos invade a dúvida de que o humano é viável até em crianças, o que resta à pedagogia e ao pensar e fazer educativos? As surpresas diante das condutas dos educandos em que tanto confiávamos nos colocam essa dúvida cruel: o humano é viável? Educável?

\section{REFERÊNCIAS}

ALEXANDER, M. El color de la justicia: la nueva segregación racial en Estados Unidos. Madrid: Capitán Swing, 2014.

ARROYO, M. G. O direito à educação e a nova segregação social e racial - tempos insatisfatórios? Educação em Revista, v. 31, n. 3, jul./set. 2015a.

; VIELLA, M. A. L.; SILVA, M. (Orgs.). Trabalho-Infância: exercícios tensos de ser criança. Haverá espaço na agenda pedagógica? Petrópolis: Vozes, 2015b.

Imagens quebradas: trajetórias e tempos de alunos e mestres. 7. ed. Petrópolis: Vozes, 2012a.

; SILVA, M. (Orgs.). Corpo-Infância: exercícios tensos de ser criança; por outras pedagogias dos corpos. Petrópolis: Vozes, 2012b.

. Direito a tempos-espaços de um justo e digno viver. In: MOLL, J. (Org.). Caminhos da educação integral no Brasil: direito a outros tempos e espaços educativos. Porto Alegre: Artmed, 2012c, p. 23-34.

BAUMAN, Z. Vidas desperdiciadas: La modernidade y sus parias. Barcelona: Paidós, 2013. 
BRASIL. Ministério da Educação e Cultura. Documento preliminar à Base Nacional Comum Curricular. Brasília: MEC, 2015.

Instituto Brasileiro de Geografia e Estatística.

Pesquisa Nacional por Amostra de Domicílios PNAD. Brasília: IBGE, 2011.

MISSE, M. Crime e violência no Brasil contemporâneo: estudos de sociologia do crime da violência urbana. Rio de Janeiro: Lumen Juris, 2006.

OLIVEIRA, F. Contos kafkianos. In: CABANES, R. et al. (Org.). Saídas de emergência. Ganhar, perder a vida na periferia de São Paulo. São Paulo: Boitempo, 2011.

SANTOS, B. S.; MENEZES, M. P. (Orgs.). Epistemologias do Sul. São Paulo: Cortez, 2009.

TAKEUTI, N. Do outro lado do espelho: a fratura social e as pulsões juvenis. Rio de Janeiro: Relume Dumará; Natal: UFRN, 2002.

TELLES, V. da S. Ilegalismos populares e relações de poder nas tramas da cidade. In: CABANES, R. et al. (Org.). Saídas de Emergência. Ganhar, perder a vida na periferia de São Paulo. São Paulo: Boitempo, 2011.

VIELLA, M. A. L.; VENDRAMINI, C. Consumindo corpos infantis e juvenis - O intrincado fenômeno da exploração sexual comercial de crianças. In: ARROYO, M. G.; SILVA, M. (Orgs.). Corpo-Infância: Exercícios tensos de ser criança; Por outras pedagogias dos corpos. Petrópolis: Vozes, 2012, p. 81-102.

WACQUANT, L. O lugar da prisão na nova administração da pobreza. Novos estudos, CEBRAP, n. 8o, p. 9-19, 2008.

WAISELFISZ, J. J. Mapa da violência: Os jovens no Brasil. Rio de Janeiro: Flacso-Brasil, 2014.

ZIZEK, S. Sobre la violência. Barcelona: Paidós, 2009.

La suspensión política de la ética. Buenos Aires: Fondo de Cultura Económica, 2005. 